\title{
Traditional Practices Prevalent among Farmers in Haveri District, Karnataka State, India Pertaining to Seed Selection, Treatment, Storage and Sowing Methods
}

\author{
B.G. Shambulingappa ${ }^{1 *}$ and C.P. Mansur ${ }^{2}$ \\ ${ }^{1}$ Animal Husbandry Polytechic, Shiggaon, India \\ ${ }^{2}$ College of Agriculture, Hanumanamatti, U.A.S. Dharwad, India \\ *Corresponding author
}

\begin{abstract}
A B S T R A C T
\section{Keywords}

Traditional knowledge, Seed storage, Seed treatment, Seed selection, Seed germination, Agriculture

Article Info

Accepted:

18 October 2018

Available Online:

10 November 2018

Agriculture, which forms the backbone of Indian economy, depended heavily on the traditional knowledge. In this study, we have documented some of the traditional practices pertaining to seed selection, treatment, storage and sowing methods prevalent among farmers in Haveri district, Karnataka state, India. Traditional methods were adopted for seed selection and treatment. The seeds were checked for their germination potential during Navratri. Applying kemmannu, neem oil, mixing with dry neem leaves, mixing with ash are common methods of seed storage. Some farmers also used to store onions, paddy in straw heaps. $65.57 \%$ of the total study participants used gunny bags for storage, $26.22 \%$ of the respondents used palatha and $8.20 \%$ of the respondents used underground silos. One of the most common methods for storage is by using neem leaves. Farmers also use lime or Calcium hydroxide for storage of seeds. Traditional sowing methods used by farmers in Haveri district include drilling, dribbling and transplanting. The sowing method used depends on the crops that the farmers intend to sow. While all three methods were used for paddy crops, drilling and dribbling were used for maize, jowar, groundnut and sunflower. Transplanting and dribbling were used for chilly and cotton crops.
\end{abstract}

\section{Introduction}

Indigenous traditional knowledge (ITK) is a collection of knowledge unique to a particular culture, society or geographical region. They have been preserved over several generations and have been efficiently used for the betterment and conservation of natural resources (Mehta et al., 2010). In indigenous practices, people have developed knowledge over a period of several centuries based on their interaction with the surrounding, thus propelling this into a primary source of knowledge (Rajagopalan, 2003). ITK among farmers has evolved through experimentation, though unintended, as a result of adaptations based on pragmatic approach to survive in a fragile soil system (Adedipe, 1983 and 1982). This knowledge system comes through generations of development, preservation and refinement as a result of interacting, observing and experimenting with the environment (Pushpangadan, 2002). Traditional knowledge has been passed on to subsequent generation 
through oral means. There are no/limited accounted versions of this knowledge, which can be preserved for future reference and dissemination (Pandey et al., 2017). The source of this knowledge base is the older generation and there is an imminent requirement to document this before they fade away (Rajagopalan, 2003). Traditional information on health, animal health, livestock management, food, agriculture, timber, dye, religious ceremonies etc. can be put into the best use for future generations through documenting. Projects associated with conservation of biological diversity, sustainable uses of natural resources, indigenous health practices etc. will be benefitted as important aspects of the ITK can be used for their proper implementation. It also increases the awareness of the younger generations towards the traditional knowledge (Pandey et al., 2017). Through the current study, an attempt has been made to document some of these practices related to agriculture for the future benefit of the mankind. Traditional practices for seed selection, treatment, storage and sowing methods prevalent among farmers in Haveri district of Karnataka state has been documented in this study.

\section{Materials and Methods}

\section{Locale of the study}

The study was conducted to analyze the folk practices followed in agriculture at Haveri district of Karnataka State, India. Haveri district is located at the center of the state of Karnataka. The district is well known for agriculture. The major crops of the region include rice, pulses, cereals and vegetables.

\section{Research design}

'Ex-post facto design' was employed in the present study as the event has already occurred and design was considered appropriate. Discussions were initiated with the farmers regarding several agricultural practices. In this study, we focussed on the information regarding the traditional practices involved in pest and disease management. In all, 122 farmers were involved in this study. All the information that was collected from the farmers during the course of discussion was noted down immediately. This information were later grouped and analyzed.

\section{Sampling technique}

The sampling technique of the farmers chosen to participate in this study was mainly based on random selection. Through this technique, every participant of the study was chosen randomly and the choice was based entirely on chance. The participants of this study were recruited through snowball sampling because the potential participants were few. This technique is a non-probability sampling technique, where the future participants are recruited by the existing participants among their acquaintances.

\section{Results and Discussion}

\section{Seed Selection}

Good seed production calls for good selection of seeds. The selection of seeds was to be done in such a way that it ensured

Healthy plant was used to select the seed Well-developed plant

Maintained the genetic quality of the seed

Traditional seed selection practices ensure that rural farming communities use seeds which are of good quality and are genetically pure. They are an integral part of informal seed systems which support sustainable production in marginal agricultural production systems. (Balcha and Tanto, 2008) 
The farmers generally selected their seeds based on the phenomena of natural selection. This method was seen as the best method to enhance the vigour of the seed. This practice has also been reported by Randhwa in 1980 . Seeds were exchanged among farmers to bring in genetic heterosis and practice rotation of variety.

\section{Seed germination checks}

The farmers use indigenous methods of germination tests in order to determine the germination potentiality or viability of the seeds. Through these methods the farmers determine the seed is able to emerge and develop into a seedling, to a stage where its structural features indicate if it would have the capability to develop into a healthy plant under the conditions provided in the field. This is also a method of sampling a few seeds from a whole resource before utilizing under field conditions. The test also helps the farmer in putting his resources under best use, by avoiding the usage of seeds which have lesser potential to germinate.

One of the methods most commonly adopted by the farmers here is to associate the germination of seeds as a part of an important celebration. A common example is the festival of Navratri, which falls in the month of OctNov. Navratri is a 9-day festival celebrated across the country. One of the most important and prevalent practices during this festival is to sow pulses, cereals and other seeds on the first day in a pot which is watered for nine days (Figure 1). This pot is worshipped throughout the nine days. These pots are considered as a symbol of prosperity and growth. The seeds sprout during the course of the festivities. In some states like Karnataka, the farming community uses a base of cow dung for sowing the seeds during Navratri. The sowing of seeds during Navratri give a good idea about the germination potential of the seeds before the next agriculture season begins. Towards the end of the 9 day celebrations, the seeds develop into seedlings, big enough to give the farmers a fair ides about the vigor of the seeds that they would use for the subsequent cropping season.

\section{Seed treatment and storage}

Seed treatment and storage comprise of one of the most important aspects of agriculture. The seed treatment practices have to appropriate to get good germination, plant establishment, and crop protection in early stage of crop growth (Mathad et al., 2013) Traditional farmers follow various methods of seed treatment. Ancient texts such as Parashara's KrishiParashara, Surapala's Vrikshayurveda, Kautilya's Arthashastra, and Varahamihira's Brihat Jataka prescribe various methods for seed treatment.

A number of factors like the humidity, temperature, packaging, storage material, gas exchange and the composition of atmosphere influence the storage. All these external factors play a role in determining the quality and time of storage. Through trial and error method, farmers have designed and developed various methods to store the farm produces and to protect them from insects and pests. It is estimated that in India, $60-70 \%$ of food grains produced is stored at home level in indigenous structures ranging from bamboo baskets to mud structures, gunny bags and modern bins (Kanwar and Sharma, 2003; Channal et al., 2004).

Applying kemmannu (red soil), neem oil, mixing with dry neem leaves, mixing with ash are common methods of seed storage. Some farmers also used to store onions, paddy in straw heaps.

In the study population here, it was observed that the farmers used different methods to 
store the seeds. The storage was dependent on the seeds that were being stored. In general, paddy, maize and jawar were stored in gunny bags, underground silo or silos made with bamboo or wood, known locally as Palatha. A majority of the farmers were found to be using gunny bags. Among the farmers who participated in the study, 80 farmers were found to be using this technique for the storage. This corresponded to $65.57 \%$ of the total study participants. They used gunny bags to store seeds like Paddy, maize, chilli, ground nut, sunflower, Jawar, cowpea etc. The next method for storage was using palatha, which was used by 32 farmers, which corresponded to $26.22 \%$ of the respondents. Underground silo was used by 10 farmers, which corresponded to $8.20 \%$ of the respondents. Both these silos were used to store crops like jawar paddy and maize. The details of the seed storage method adopted by these farmers have been summarized in Table 1. A representation of on ground seed storage silo also known as Kanaja is shown in figure 2.
One of the most common methods for storage is by using neem leaves. In Ratnagiri district of maharashtra, leaves of neem (Melia azadirachta), or nigadi (Vitex negundo), or teak (Tectona grandis) trees or fruits of Kubhali or Triphala (Zanthozylum rhesta) or gelkand were mixed in the grains by the farmers. They reported that rice were soaked in thin slurry of 1 portion of cow dung and 2 portions of cow urine for half an hour and dried in shade. After complete drying, these seeds were stored with leaves of neem (Azadirachta indica) and banyan trees. Finally, the whole structure was covered with cow dung. (Anonymous 2000) Some farmers also use neem leaves along with leaves from other plants to protect ragi from the storage pests. Neem leaves help in keeping pests like grain borers (Rhyzopertha dominica), saw toothed beetle (Oryzaephilus surinamemsis) and flat grain beetle (Cryptolestes minutus) away. Neem oil and neem seed kernels are also used as pest repellants. (Karthikeyan et al., 2007)

Fig.1 Check seed germination in cow dung during Mahanavami festival

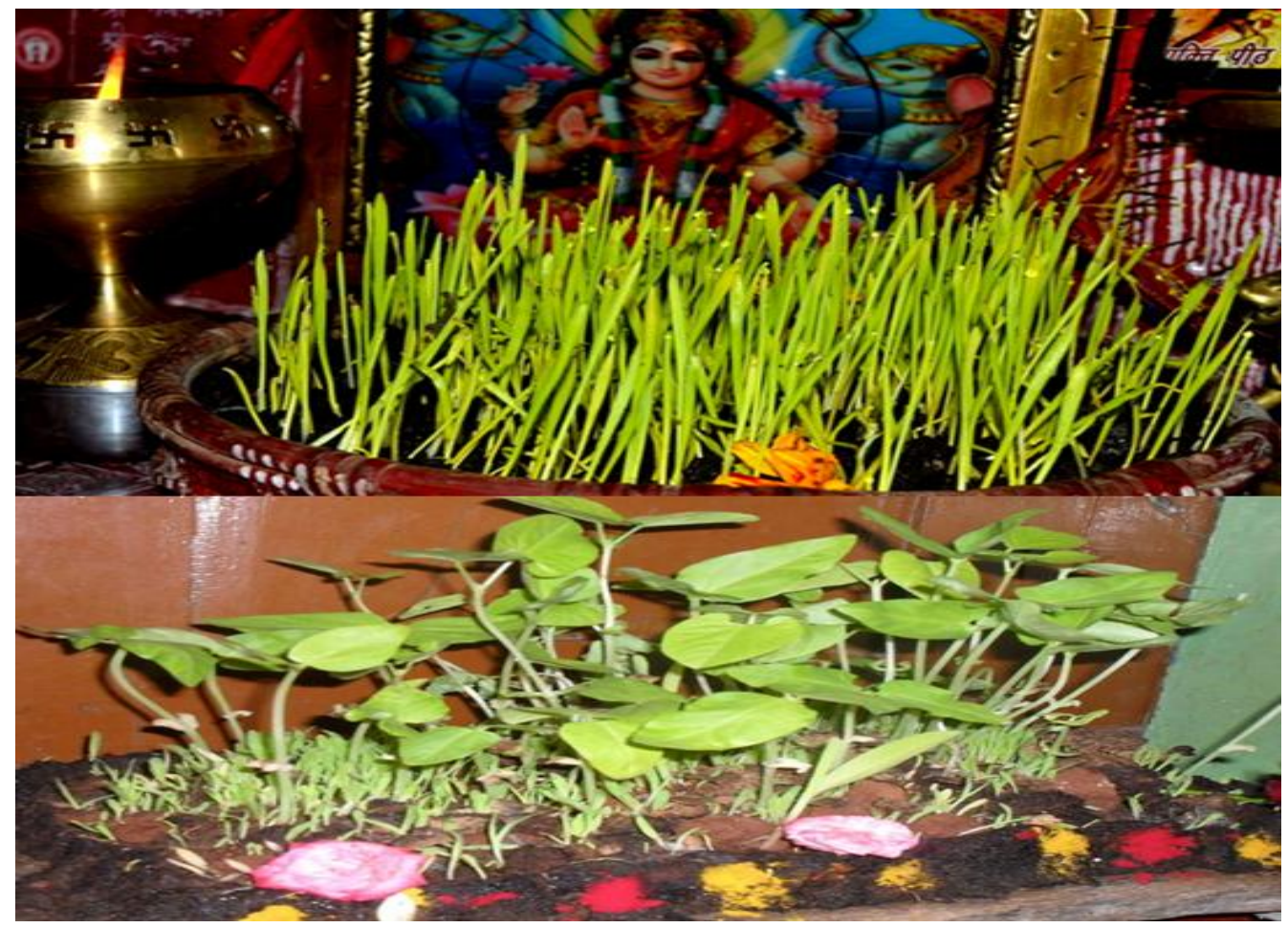


Fig.2 Kanaja (on the ground seed storage silo)

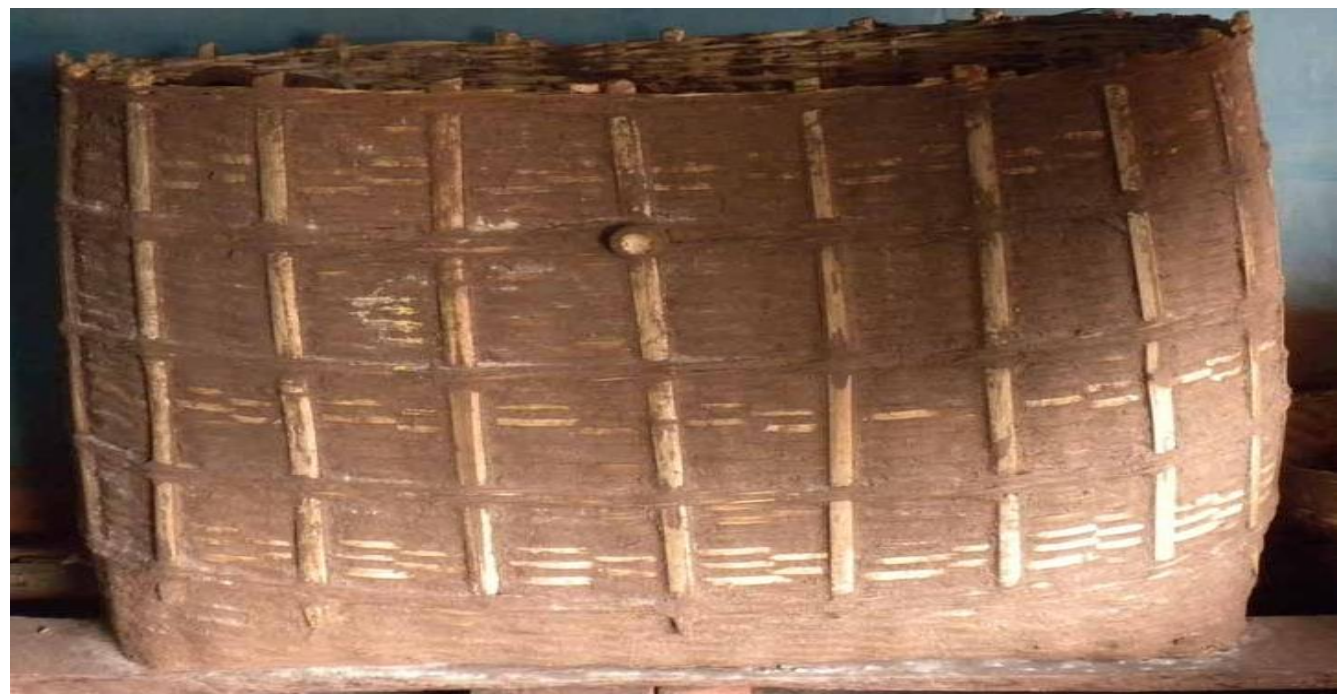

Fig.3 Nellu (hanging rope) for storage of jaggary and Hagevu (underground seed storage silo)

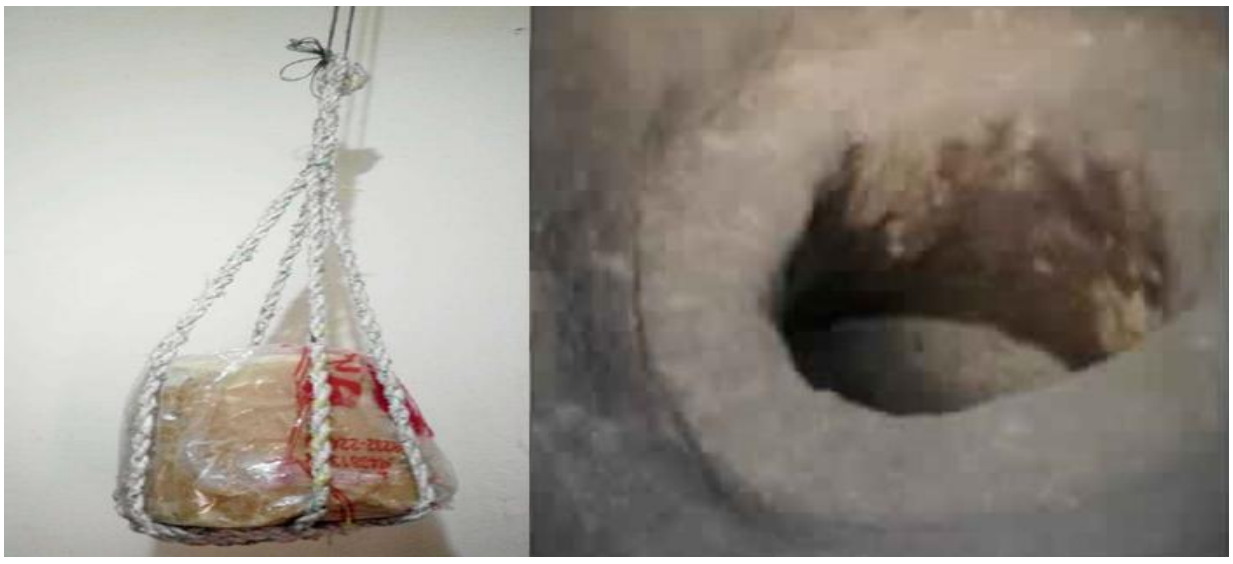

Fig.4 Seed drilling method

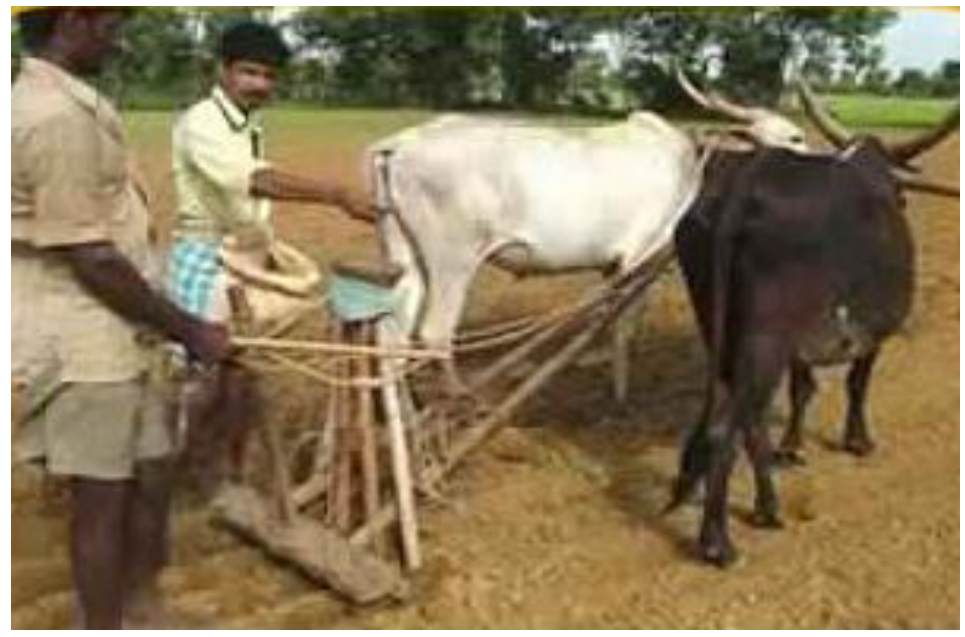


Fig.5 Seed dribble method

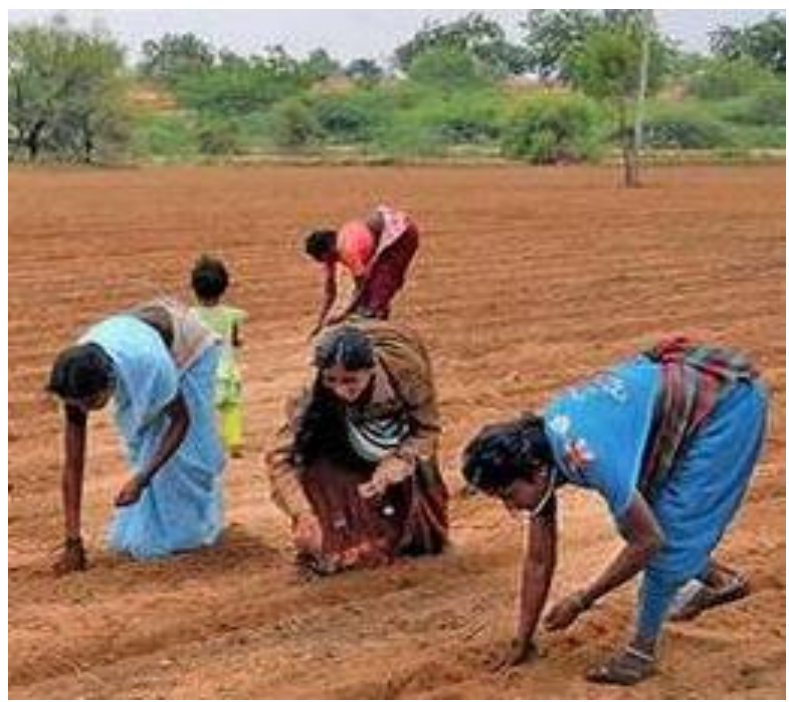

Fig.6 Transplanting method

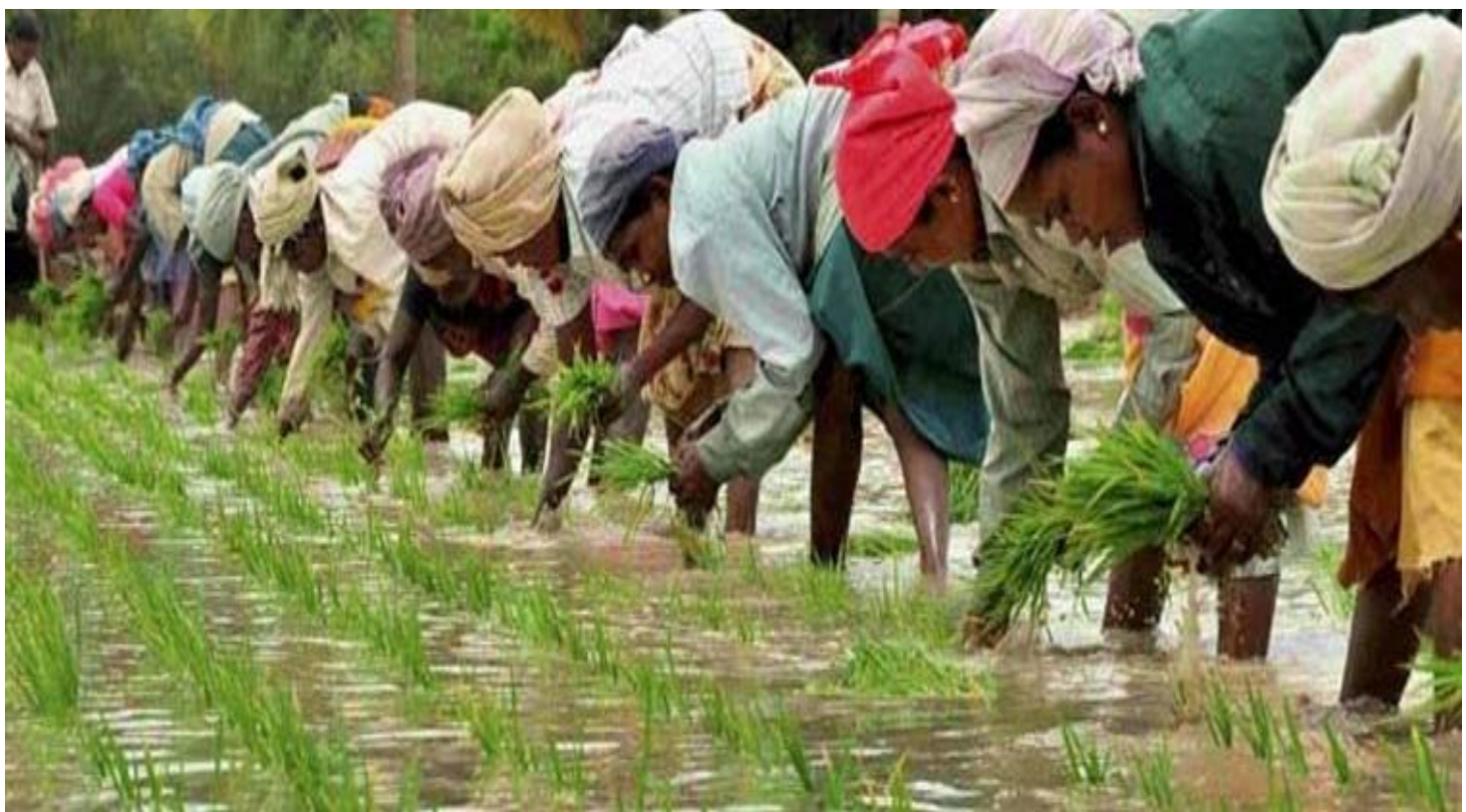

Table.1 Typical ways of storage of seeds and crops

\begin{tabular}{|c|l|l|c|c|}
\hline $\begin{array}{c}\text { Sl. } \\
\text { No. }\end{array}$ & Method of storage & \multicolumn{1}{|c|}{ Seeds/Crops } & No of farmers & $\begin{array}{c}\text { Percentage of } \\
\text { respondents }\end{array}$ \\
\hline $\mathbf{1}$ & Gunny bags & $\begin{array}{l}\text { Paddy, maize, chilli, ground nut, } \\
\text { sunflower, Jawar, cowpea }\end{array}$ & 80 & 65.57 \\
\hline $\mathbf{2}$ & Underground silo & Jawar, paddy, maize & 10 & 8.20 \\
\hline $\mathbf{3}$ & $\begin{array}{l}\text { Palatha (Bamboo or } \\
\text { wooden silo) }\end{array}$ & \begin{tabular}{l} 
Paddy, Maize, Jawar \\
\hline
\end{tabular}
\end{tabular}


Table.2 Sowing methods adopted by the farmers for various crops

\begin{tabular}{|c|l|l|}
\hline SI. No & \multicolumn{1}{|c|}{ Crops } & Seed sowing method followed \\
\hline 1 & Paddy & Drilling, dribble, transplanting \\
\hline 2 & Maize & Drilling, dribble \\
\hline 3 & Jawar & Drilling, dribble \\
\hline 4 & Groundnut & Drilling, dribble \\
\hline 5 & Sunflower & Drilling, dribble \\
\hline 6 & Chilly & Transplanting, dribble \\
\hline 7 & Cotton & Dribble, transplanting \\
\hline
\end{tabular}

Products of neem leaves are available in plenty in rural areas. These traditional methods using the products of neem trees are very easy to be put into practice. Moreover, these products are easily available and hence, the cost for practicing these methods will be very cheap. This prompted some of the farmers to make use of these traditional practices to get rid of the pests rather than relying on chemical methods which will be more expensive and harmful.

Another method commonly adopted by farmers is to use lime or Calcium hydroxide for storage of seeds. This method involved mixing of lime with water, allowing it to settle down and soaking the seeds in the supernatant. This is also a cheap alternative for chemical methods, without any side effects. The chemical component, calcium hydroxide present in lime confers protection against various diseases like smut and bunt. (Mathad et al., 2013)

Other methods include use of cow urine, salt water, cow dung, storing seeds along with horse gram seeds and plant dusts, coating seeds with fine red soil from the village pond, using bitter gourd powder and drumstick extract etc. Seeds treatment with cow dung helps to prevent microbial attack to seeds in soil, mimics rizobium treatment like conditions in modern agriculture, its source of micro-nutrients, attract useful microbes (commensals) towards plant seeds. Figure 3 represents some of the traditional storage practices in Haveri district.

\section{Seed sowing methods}

Traditional sowing methods used by farmers in Haveri district include drilling, dribbling and transplanting. The sowing method used depends on the crops that the farmers intend to sow

Drilling: This is one of the most common methods that the farmers in Haveri district adopted for agriculture (Figure 4). They were using this method for crops like paddy, maize, jowar, groundnut, sunflower, chilly and cotton.

In this method, seeds are dropped on the soil with the help of certain specific implements. The implements used may be seed drill, seedcum-fertilizer driller or mechanical seed drill. A contact is established between the seed and soil using a wooden plank.

\section{Dribbling}

This method was as popular as seed drilling among the farmers of Haveri district. They were using this method for crops like paddy, maize, jowar, groundnut, sunflower, chilly and cotton along with seed drilling.

The process of dribbling is done manually. It involves placing or dribbling of seeds at 
specific cross marks made in the field with the help of maker as per the requirement of the crop in both the directions (Figure 5).

Transplantation: This method was less popular among the farmers in Haveri district. One of the probable reasons that the researcher thinks could be because of the extra care that the plant may require at the nursery and the cost involved. The farmers involved in the study were seen to be using this technique for crops like paddy, chilly and cotton along with other methods like drilling and dribbling.

In this method, the seeds are allowed to grow as seedlings in the nursery and later transplanted into the fields. Before transplantation, the seedlings are allowed to grow in the nursery for a period of 3-5 weeks. The field should be well irrigated before transplantation. This would enable the seedlings to establish themselves well to the field conditions. This also ensures that most of the seedlings retain their viability (Figure $6)$.

For the crops that were a part of this study, it was seen that more than one of the abovementioned methods was used in combination. While all three methods were used for paddy crops, drilling and dribbling were used for maize, jowar, groundnut and sunflower. Transplanting and dribbling were used for chilly and cotton crops. The sowing methods adopted by the farmers for various crops have been summarized in Table 2 .

Though ITKs originated in the ancient period and have been practiced by people from time immemorial, no written documents are available for recording and disseminating it. Uncontrolled usage of such output-oriented farming practices has led to deterioration of soil fertility, increased accumulation of chemicals in the form of fertilisers and pesticides in food products, single cropping, and loss of wild crop and seed varieties (Sugam et al., 2016). Hence, the awareness among the researchers about the importance of these traditional practices is on the rise and the practices have to be documented for every community (Brokensha, 1990). ITK has the advantage of being cost effective and readily available. They are very effective in solving problems of local nature and have many a times beaten the modern technology by offering the better solution. In spite of these advantages, very few attempts have been made to collect, record and analyze them (Pandey et al., 2017). Through the current study, the researcher has attempted to record the prevalence of traditional practices pertaining to agriculture in the Haveri district of Karnataka state.

\section{References}

Adedipe, N.O. 1983a. A Functional Modality for the Improvement of AgroNutritional Quality in Rural Nigeria. In:

Rural Nigeria: Development and Quality of Life. U. Igbozurike and R. Raza (eds.), 91-97. ARMTI. Seminar Series No. 3. Agricultural and Rural Management Training Institute, Ilorin, Nigeria. pp. 308.

Adedipe, N.O. 1984. Environmental Considerations of Shifting Cultivation in Africa and the Task of Universities, A.H. Bunting and E. Bunting (eds.).Proceedings of the International Workshop on Shifting Cultivation: Teaching and Research at the University Level, July 4-9, 1982. University of Ibadan, Nigeria. Food and Agricultural Organization, Rome, pp. 192.

Adedipe, N.O., 1983b. Strategies for Increasing Food Production in Nigeria, 109-116. In: Nutrition and Food Policy in Nigeria. T. Atinmo and L. Akinyele 
(eds.). National Institute for Policy and Strategic Studies, Jos, Nigeria, pp.447.

Balcha G. \& T. Tanto. 2008. Conservation of genetic diversity and supporting informal seed supply in Ethiopia. Eds. M.H. Thijssen, Z. Bishaw, A. Beshir, \& W.S. de Boef. In: Farmers' seeds and varieties: supporting informal seed supply in Ethiopia. Pp. 141-149. Wageningen International, Wageningen, The Netherlands.

Brokensha D. 1990. Indigenous knowledge system and development. University Press of America; 111-27.

Mathad RC, Vasudevan SN, Mathad NC, and SB Patil., 2013. Traditional Seed Treatment and Storage Methods of Northeastern Region of Karnataka. Asian Agri-History Vol. 17 (3): 233 239.

Mehta, P.S., Sharma A.K., and Negi KS. 2010. Indigenous knowledge system and sustainable development with particular reference to folklore practices in Kumaon hills, Uttarakhand. Indian
Journal for Traditional Knowledge Vol 9 (3): 547-550.

Pandey V, Mittal R and Sharma P. 2017. Documentation and Application of Indigenous Traditional Knowledge (ITK) for Sustainable Agricultural Development. Asian Journal of Agricultural Extension, Economics \& Sociology 15(3): 1-9

Pushpangadan PS, Rajasekharan, George V., 2002, Indigenous Knowledge and benefit sharing - A TBGRI experiment In IK strategies for Kerala (NSE Publication, Thiruvananthapuram); 27479.

Rajagopalan, C, Indigenous knowledge/CFS experience. 2003. Indian Journal for Traditional Knowledge Vol 2 (4): 313320.

Sugam RK, Choudhury P and Hartl J. 2016. Promoting Neo-traditional Agriculture to Achieve Food and Livelihood Security, and Climate Change Adaptation. Council on Energy, Environment and water. July, New Delhi, India.

\section{How to cite this article:}

Shambulingappa, B.G. and Mansur, C.P. 2018. Traditional Practices Prevalent among Farmers in Haveri District, Karnataka State, India Pertaining to Seed Selection, Treatment, Storage and Sowing Methods. Int.J.Curr.Microbiol.App.Sci. 7(11): 2421-2429.

doi: https://doi.org/10.20546/ijcmas.2018.711.276 